\section{Band 28, Heft 3, Juni 2012}

Editorial

162 Die Kolondivertikulose und ihre Komplikationen Meyer, H.-J. (Solingen); Kruis, W. (Köln)

Hauptthema

164 Pathogenese der Divertikulose und Divertikelkrankheit des Kolons

Wedel, T.; Barrenschee, M.; Hellwig, I.; Harde, J.; Böttner, M. (Kiel)

171 Diagnostik und Klassifikation der Divertikelkrankheit

Böhm, S.K. (Essen)

182 Möglichkeiten und Grenzen der ambulanten Therapie der Divertikelkrankheit

Helwig, U. (Oldenburg)

190 Operationsindikationen bei der Divertikelkrankheit von Rahden, B.H.A.; Germer, C.-T. (Würzburg)

196 Notfalleingriffe bei der komplizierten Divertikulitis Ritz, J.-P. (Schwerin); Buhr, H.J.; Holmer, C. (Berlin)

201 Persistierende Beschwerden nach elektiver Sigmaresektion wegen Sigmadivertikulitis Pfützer, R.H. (Köln)

Interdisziplinäres Gespräch

206 Die Kolondivertikulose und ihre Komplikationen Fischbach, W. (Aschaffenburg) (Gesprächsleiter)

Originalarbeit

211 Risikofaktoren und Langzeitiiberlebensraten bei Patienten mit Magenkarzinom nach radikaler Resektion: Analyse einer homogenen Patientenpopulation aus Warschau, Polen Gierej, P.; Radziszewski, J. (Warsaw)
Vol. 28, Issue 3, June 2012

\section{Editorial}

162 Diverticulosis of the Colon and Associated Complications

Meyer, H.-J. (Solingen); Kruis, W. (Köln)

Main Topic

164 Pathogenesis of Diverticulosis and Diverticular Disease of the Colon

Wedel, T.; Barrenschee, M.; Hellwig, I.; Harde, J.; Böttner, M. (Kiel)

171 Diagnosis and Classification of Diverticular Disease Böhm, S.K. (Essen)

182 Possibilities and Limits in the Treatment of Diverticular Disease in an Outpatient Setup Helwig, U. (Oldenburg)

190 Surgical Indications for Colonic Diverticular Disease

von Rahden, B.H.A.; Germer, C.-T. (Würzburg)

196 Emergency Surgery in Complicated Diverticulitis Ritz, J.-P. (Schwerin); Buhr, H.J.; Holmer, C. (Berlin)

201 Persisting Symptoms after Elective Sigmoid Resection for Sigmoid Diverticulitis Pfützer, R.H. (Köln)

Interdisciplinary Discussion

206 Diverticulosis of the Colon and Associated Complications

Fischbach, W. (Aschaffenburg) (Discussion Leader)

Original Article

211 Risk Factors and Survival of Gastric Cancer Patients Following Curative Stomach Resection: Analysis of a Homogeneous Population of Patients in Warsaw, Poland

Gierej, P.; Radziszewski, J. (Warsaw)

\section{KARGER}

Fax +497614520714

Information@Karger.de

www.karger.com (c) 2012 S. Karger GmbH, Freiburg 


\section{Band 28, Heft 3, Juni 2012}

Fallbericht

216 Kongenitale Diaphragmahernie mit spontaner Magenruptur während der Schwangerschaft

Shen, C.-L.; Huang, T.-W.; Huang, H.-K.; Hsieh, C.-M.;

Cheng, Y.-L.; Chang, H.; Tzao, C.; Hsu, H.-H.; Lee, S.-C. (Taipei)

219 News / Ticker

221 Tagungen und Kongresse

224 Hinweise für die Autoren

205 Impressum
Vol. 28, Issue 3, June 2012

Case Report

216 Congenital Diaphragmatic Hernia with Spontaneous Gastric Rupture in Pregnancy

Shen, C.-L.; Huang, T.-W.; Huang, H.-K.; Hsieh, C.-M.; Cheng, Y.-L.; Chang, H.; Tzao, C.; Hsu, H.-H.; Lee, S.-C. (Taipei)

219 News / Ticker

221 Meetings and Conferences

224 Guidelines for Authors

205 Imprint

\section{KARGER}

(C) 2012 S. Karger GmbH, Freiburg 